\title{
Noninvasive Estimation of Cerebral Perfusion Pressure with Transcranial Doppler Ultrasonography in Traumatic Brain Injury
}

\section{Travmatik Beyin Hasarnda Transkranial Doppler Ultrasonografi ile Noninvaziv Olarak Serebral Perfüzyon Basıncının Hesaplanmast}

\author{
Melek GURA ${ }^{1}$, Gokalp SILAV ${ }^{2}$, Nejat ISIK $^{3}$, Ilhan ELMACI ${ }^{2}$ \\ ${ }^{1}$ M.H. Istanbul Medeniyet University, Goztepe Education and Research Hospital, Department of Anesthesiology and Reanimation, \\ Istanbul, Turkey \\ ${ }_{2}^{2}$ Acibadem Maslak Hospital, Department of Neurosurgery, Istanbul, Turkey \\ ${ }^{3}$ M.H. Istanbul Medeniyet University, Goztepe Education and Research Hospital, Department of Neurosurgery, Istanbul, Turkey
}

Correspondence address: Gokalp SILAV / E-mail: gsilav@yahoo.com

\begin{abstract}
AIM: In traumatic brain injury (TBI) patients, to overcome the secondary insults, cerebral perfusion pressure (CPP) oriented therapy is recommended. The study is assigned to estimate CPP values with middle cerebral artery (MCA) flow velocities measured noninvasively using transcranial Doppler ultrasonography (TCD).

MATERIAL and METHODS: Forty-seven TBI patients were studied. Intracranial pressure (ICP), mean arterial pressure (MAP) and MCA flow velocities of the patients were monitored. Invasive CPP was calculated as the difference between MAP and ICP. The formula :'MAP x FVd/FVm $+14^{\prime}$ was used to estimate CPP noninvasively. Correlation of the noninvasive and invasive values were analysed.

RESULTS: The mean values of noninvasive CPP and invasive CPP were $66.10 \pm 10.55 \mathrm{mmHg}$ and $65.40 \pm 10.03 \mathrm{mmHg}$ respectively. The correlation between noninvasive and invasive CPP measurements was strongly significant $(p<0.001)$ with a correlation coefficient of $r=0.920$. CONCLUSION: With ICP monitoring systems, CPP is calculated and the therapy is guided according to these values. As it is recognized that brain perfusion can be assessed with TCD waveforms, noninvasive CPP estimation with MCA flow velocities may help to observe the trends in CPP values.
\end{abstract}

KEYWORDS: Cerebral perfusion pressure, Estimated cerebral perfusion pressure, Transcranial doppler ultrasonography, Traumatic brain injury

Öz

AMAÇ: Travmatik beyin hasarında, ikincil hasarın önlenebilmesi için serebral perfüzyon basıncına yönelik tedaviler önerilmektedir. Çalışmamızda, serebral perfüzyon basıncı, noninvaziv olarak transkranial doppler ultrasonografi ile orta serebral arter akım hızının ölçülmesi ile hesaplanmıştır.

YÖNTEM ve GEREÇLER: Kırkyedi travmatik beyin hasarlı hasta çalışmaya dahil edilmiştir. İntrakranial basınç, ortalama arteriyel basınç ve orta serebral arter akım hızları izleme alınmıştır. Serebral perfüzyon basıncının invaziv takibi ortalama arteriyel basınç ile intrakranial basınç farkı alınarak bulunmuştur. Serebral perfüzyon basıncının noninvazif olarak bulunmasında 'MAP x FVd/FVm +14' formülü kullanışmıştır. İnvaziv ve noninvaziv değerler arasında ki ilişki analiz edilmiştir.

BULGULAR: Noninvaziv ve invaziv serebral perfüzyon basıncı ölçümleri ardışık olarak $66.10 \pm 10.55 \mathrm{mmHg}$ ve $65.40 \pm 10.03 \mathrm{mmHg}$ 'dır. Noninvaziv ve invaziv serebral perfüzyon basıncı ölçümleri arasındaki ilişki belirgin bir şekilde kuvvetlidir $(p<0.001$, korelasyon katsayısı $r=0.920)$.

SONUÇ: İntrakranial basınç ölçüm sistemleri ile serebral perfüzyon basıncı hesaplanarak tedavi bu değerlere göre düzenlenmektedir. Tanımlandığı gibi transkranial doppler ultrasonografi ile beyin perfüzyonu hesaplanabilir. Orta serebral arter akım hızları ile serebral perfüzyon basıncının noninvaziv olarak hesaplanması, basınç değişikliklerinin ölçülmesinde yardımcı olabilir.

ANAHTAR SÖZCÜKLER: Serebral perfüzyon basıncı, Serebral perfüzyon basıncının ölçülmesi, Transkraniyal doppler ultrasonografi, Travmatik beyin hasarı 


\section{INTRODUCTION}

The main management strategy to limit secondary cerebral insults in TBI is cerebral oxygenation. Cerebral oxygenation is followed up with cerebral blood flow (CBF), arterial oxygen content, and cerebral metabolic rate of oxygen consumption. The latter two are not practical in daily practice in neurointensive care units. CPP is the one mostly used as a surrogate of CBF measurements $(33,34)$. In the early management of TBI patients, it is important to guide the therapy and evaluate the outcome according to the ICP and CPP values (17). If autoregulation is preserved, protection against secondary brain insults will be provided $(6,12,14,21,29,30)$. In the assessment of CPP, even though an ICP measurement is needed to calculate CPP as the difference between MAP and ICP, some propose that it is not always adequate and that it may be better to evaluate it on the basis of cerebral blood flow and brain oxygenation $(23,27)$. However, continuous CBF measurement is not easy. At this point, TCD ultrasonography evaluation is recommended. The flow velocity measurements of MCA flow velocity has been proposed as an alternative for cerebral monitoring and several methods have been used to estimate CPP with TCD velocities $(1,8,9,10,25,31,33)$. This study is designed to investigate whether the noninvasive measurement of CPP would help to manage the patients vigorously before the attempts of ICP monitoring.

\section{MATERIAL and METHODS}

A prospectively collected records of 47 patients with isolated TBI in neurointensive care unit of Istanbul Göztepe Training Hospital were reviewed and approved by the institutional ethical committee. Inclusion criteria were GCS $\leq 8$ in the emergency department and cerebral computed tomographic (CT) scans had to demonstrate findings of brain injury. CT scan results were classified according to the changes seen on CT scan, defined by Marshall et al. (15). Exclusion criteria included death within 24 hours of admission, organ failure or haemodynamic instability. The patients were intubated, sedated, mechanically ventilated and haemodynamic support was performed consequently. The head was elevated 30 degrees upwards. Arterial blood pressure was monitored in all patients by radial artery catheter. MAP was monitored continuously. ICP monitoring was initiated for patients with a GCS $\leq 8$, unilateral or bilateral motor posturing, or systolic blood pressure $<90 \mathrm{mmHg}$. A parenchymal catheter (Integra MPM-1) was placed. ICP was measured and recorded continuously in a software data. CPP was calculated from the difference between MAP and ICP.

The daily TCD measurements were conducted transtemporally using a traditional $2 \mathrm{MHz}$ transducer (DWL) with mechanically fixed in place probe holders and were recorded continuously. The depth and angle of insonation giving the highest mean flow velocity was chosen. Mean (mFV), diastolic (dFV) and systolic flow velocities were recorded. TCD monitoring was performed as long as the ICP monitoring continued. The measurements were recorded at the same time in the individual patient in the first 24 hours. The control of elevated
ICP (> $20 \mathrm{mmHg}$ ) was managed according to the guidelines of Brain Trauma Foundation (BTF) (29). MAP of $90 \mathrm{mmHg}$, CPP $60-70 \mathrm{mmHg}$, ICP $<20 \mathrm{mmHg}$, central venous pressure $5-10 \mathrm{mmHg}$ and $\mathrm{SaO} 2>95 \%, \mathrm{PaCO}_{2}$ of $30-35 \mathrm{mmHg}$ and temperature between $35^{\circ}-37^{\circ} \mathrm{C}$ were targeted. Prophylactic hyperventilation was not performed. Decreases of MAP which would reduce the CPP values were managed with colloid, normal saline or inotropic agents. Noninvasive CPP (eCPP) was calculated according to the following formula: $e C P P=$ $M A P \times d F V / m F V+14$ (23).

The statistical analysis was performed in SPSS 15.0 For Windows for data processing and analysis. The definitive analysis was used for mean, standard deviation, minimum and maximum variables. Pearson's Correlation Analysis ( $r$ ) for correlations. The statistical significance of the correlation between the investigated quantitative variables was achieved by the $p$ level and the significance level was recorded as $p<$ 0.05 .

\section{RESULTS}

Forty seven TBI patients 37 male and 10 female, with a mean age of $34.14 \pm 19.45$ and mean GCS of $7.17 \pm 3.55$ were included in the study. Sixteen traumatic subarachnoid haematoma, 10 contusional haematoma, 7 diffuse oedema, 6 epidural haematoma, 5 diffuse axonal injury and 3 subdural haematoma patients were within the study group. The mean value of MAP ranged between $68-117 \mathrm{mmHg}$ (73.64). The mean value of noninvasive estimation of left and right CPP values was $66.10 \pm 10.55 \mathrm{mmHg}$. The mean value of invasive CPP was $64.40 \pm 10.03 \mathrm{mmHg}$ (Table I). The correlation between noninvasive and invasive CPP measurements was strongly significant $(p<0.0001)$ with a correlation coefficient of $r=0.920$ (Figure 1).

\section{DISCUSSION}

The measurement and management of both ICP and CPP are recommended in TBI patients. A correlation has been demonstrated between noninvasive TCD measurements and invasively obtained ICP and CPP values (17). However, ICP monitoring is invasive and has disadvantages of infection, haemorragia, malfunction, obstruction or malposition. Thus, TCD has been proposed as a safe technique with no reports of technique-related complications and to assess brain perfusion noninvasively. The device is of potential benefit for intermittent or continuous monitoring of brain perfusion in the situations where the direct measurement is not available or its reliability is in question $(20,22,24,25)$. Independent of the type of intracranial pathology, a strong correlation between PI and ICP is demonstrated. Therefore, PI may be

Table I: Definitive Statistics of the 47 Patients

\begin{tabular}{|l|c|c|c|}
\hline CPP & n & mean $(\mathrm{mm} / \mathrm{Hg})$ & \pm SD \\
\hline Noninvasive & 47 & 66.10 & 10.55 \\
\hline Invasive & 47 & 65.40 & 10.03 \\
\hline Difference & 47 & 0.70 & 4.15
\end{tabular}




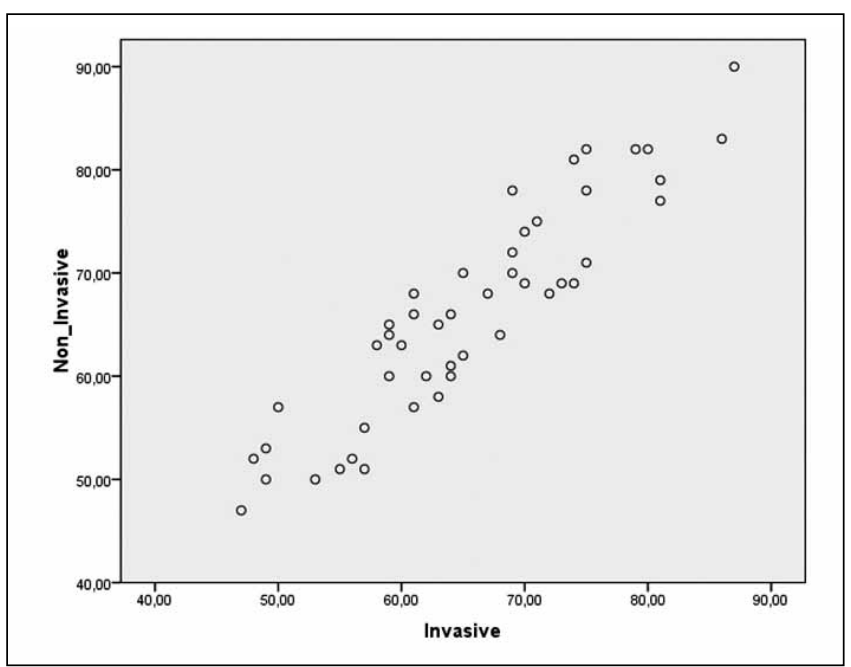

Figure 1: Correlation of invasive and noninvasive CPP values $(n=47)(r=0.920)(p<0.001)$.

of guiding value in the invasive ICP placement decision in the neurointensive care patient. Continuous waveform analysis of MCA FV and CPP correlates with coma score after resuscitation and outcome and hence may be considered as a robust method for the assessment of autoregulation in ventilated head trauma patients.

CPP is estimated as the difference between inflow (MAP) and outflow (ICP). ICP measurements have a limited value as catheters are placed in one hemisphere and drift of ICP transducers as a source of misinterpretation. In addition, MAP measured from peripheral arteries is not always the same with basal arteries. Thus, it is proposed that perfusion is better presented by CBF rather than numerical values (23). However, the bedside continuous monitoring of CBF is not so easy. It is pointed out that increase in TCD pulsatility, decrease in diastolic velocity or a decrease in the ratio of diastolic to mean flow velocity will demonstrate the problem in cerebral perfusion $(5,7,13,19,35)$.

Aaslid et al. have determined CPP with TCD parameters using the formula eCPP $=F V m X A_{1} / F_{1}\left(F_{1}=\right.$ amplitude of the fundamental frequency components of flow velocity and $A_{1}$ $=$ amplitude of the fundamental frequency components of arterial pressure), the fundamental frequency is determined by fast Fourier analysis of the waveform and is equivalent to the heart rate. Ten patients with supratentorial hydrocephalus have been studied and changes in estimated CPP have strongly correlated with the calculated CPP changes (1).

According to the Starling's resistor phenomenon at the level of cerebral veins, ICP is thought to represent the effective downstream pressure of the cerebral circulation. The cerebral pressure would stop if the mean arterial pressure equals effective downstream pressure. The effective downstream pressure has also been termed as critical closing pressure or zero flow pressure (ZFP); this is also estimated using the relationship eCPP $=$ MAP - ZFP. Since Aaslid' study, several studies on estimating CPP and ZFP have been performed $(2,3,8,16,23)$. Most of them are based on systolic, diastolic, mean flow velocities related to systolic, diastolic, mean arterial pressures. The main principle is that, perfusion pressure equals the product of flow and resistance. In Weyland's study, it was shown that in the absence of intracranial hypertension, ZFP was not the same value with ICP related to vascular wall tension, however, Buhre et al. in their study showed that there was a correlation observed between ZFP and ICP in patients with intracranial hypertension $(4,32)$.

Belfort et al. studied the change in estimated CPP treated with nimodipine and magnesium sulfate in patients with preeclampsia. The formula used was: eCPP $=V_{\text {mean }} X$ (MAP - $D A B) / V_{\text {mean }}-V_{\text {diast }}$. In intergroup comparisons, there were significant differences in estimated CPP values; as an increase after nimodipine and decrease after magnesium sulfate infusions (3). The reports performed by Stacey et al and Hancock et al. suggest that the results of Belfort's formula are not related to changes in ICP or systemic vascular resistance or changes in end tidal carbon dioxide $(11,26)$.

Edouard et al. used the same formula with Belfort to estimate CPP values in $20 \mathrm{TBI}$ patients. Ten patients under stable conditions and the other ten patients under $\mathrm{CO}_{2}$ reactivity test were compared. In the stable group, measured and estimated CPP values correlated, in the other group with increased ICP values due to $\mathrm{CO}_{2}$ reactivity test performed, a significant correlation was also found (10).

Steiner et al. say that the behavior of diastolic velocity becomes important in cases of high ICP. In patients with a normal ICP, MAP is the best estimator of CPP. Methods that estimate CPP as a fraction of MAP derived from the transcranial waveform is more accurate. Using the distance between mean and diastolic values for flow velocity or blood pressure weakens the estimation of CPP (28).

In the present study, it was investigated whether the CPP measured with noninvasive technique could be reliable to predict the calculated value of the invasive method. The results of the comparison between noninvasive and invasive CPP presented a close linear correlation in the whole group with a correlation coefficient of $0.920(p<0.001)$ (Figure 1).

In this study, cerebral perfusion is assessed with TCD waveforms, from the point of view that diastolic and mean flow velocities reliably indicate the brain perfusion. The mean values of the flow velocities were taken into consideration. The main limitation of this study is that the sample size is small and variability of interpersonal and interdevice performances are to be considered. Even though the methods proposed recently are of limited accuracy, a strong correlation was observed between the noninvasive and invasive values with the formula presented with Schmidt et al. (23). They have studied 25 patients under a treatment protocol targeting CPP above $70 \mathrm{mmHg}$, monitored ICP and MCA blood flow velocities with a prototype bilateral transcranial Doppler machine built in algorithm to assess CPP. Time averaged 
values of flow velocities were calculated and put in a formula: $' e C P P=M A P X d F V / m F V+14$ '. Absolute difference between the noninvasive and invasive measurements was less than 10 $\mathrm{mmHg}$ in $89 \%$ of the measurements and less than $13 \mathrm{mmHg}$ in $92 \%$. In side to side differences, the estimated CPP values were higher in swollen hemisphere as established with CT images (23).

It is suggested that limited data of several methods although not accurate to estimate absolute ICP, may help to assess the changes in CPP and ZFP (18). However, critical appraisal of different methods, in particular of the noninvasive methods, and the relative advantages of one method over the other in a given situation, is still needed. It is difficult to judge which method of CPP evaluation is better.

However, even though the invasive ICP monitoring may not be replaced with noninvasive methods, a real-time assessment of CPP with a noninvasive method may help to observe the baseline value and follow the trend of CPP whether there is a decline or incline and help to manage intensity of the therapy in a TBI patient.

\section{REFERENCES}

1. Aaslid R, Lundar T, Lindegaard KF, Nornes H: Estimation of cerebral perfusion pressure from arterial blood pressure and transcranial recordings. In: Miller J, Teasdale G, Rowan J, Galbraith SL, Mendelow A, (eds), Intracranial Pressure VI. Berlin: Springer, 1986:226-229

2. Aaslid R, Lash SR, Bardy GH, Gild WH, Newell DW: Dynamic pressure-flow velocity relationships in the human cerebral circulation. Stroke 34:1645-1649, 2003

3. Belfort MA, Saade GR, Yared M, Grunewald C, Herd JA, Varner $\mathrm{MA}$, Nisell $\mathrm{H}$ : Change in estimated cerebral perfusion pressure after treatment with nimodipine or magnesium sulfate in patients with preeclampsia. Am J Gynecol 181: 402-407, 1999

4. Buhre W, Heinzel FR, Grund S, Sonntag H, Weyland A: Extrapolation to zero-flow pressure in cerebral arteries to estimate intracranial pressure. Br J Anaesth 90:291-295, 2003

5. Chan KH, Miller DJ, Dearden M, Andrews PJ, Midgley S: The effect of changes in cerebral perfusion pressure upon middle cerebral artery blood flow velocity and jugular bulb venous oxygen saturation after severe brain trauma. J Neurosurg 77:55-61, 1992

6. Cremer O, van Dijk G, Amelink G: Cerebral hemodynamic responses to blood pressure manipulation in severely headinjured patients in the presence or absence of intracranial hypertension. Anest Analg 99: 1211-1217, 2004

7. Czosnyka M, Matta BF, Smielewski P,Kirkpatrick PJ, Pickard JD: Cerebral perfusion pressure in head-injured patients: A non-invasive assessment using transcranial Doppler ultrasonography. J Neurosurg 88:802-808, 1998

8. Czosnyka M, Smielewski P, Piechnik S, Al-Rawi PG, Kirkpatrick PJ, Matta BF, Pickard JD: Critical closing pressure in cerebrovascular circulation. J Neurol Neusurg Psychiatry 66: 606-611, 1999
9. Czosnyka M, Smielewski P, Piechnik S, Steiner LA, Pickard JD: Cerebral autoregulation following head injury J Neurosurg 95:756-763, 2001

10. Edaudard AR, Vanhille E, Le Moigno S, Benhamou D, Mazoit JX: Noninvasive assessment of cerebral perfusion pressure in brain injured patients with moderate hypertension $\mathrm{Br} J$ Anaest 94: 216-221, 2005

11. Hancock SM, Mahajan RP, Athanassiou L: Effects of changes in end tidal carbon dioxide on estimated cerebral perfusion pressure and zero flow pressure in healthy volunteers. Anesth Analg 96:847-851, 2003

12. Juul N, Morris GF, Marshall SB, Marshall LF: Intracranial hypertension and cerebral perfusion pressure: Influence on neurological deterioation and outcome in severe head injury. J Neurosurg 92:1-6, 2000

13. Klingelhofer J, Conrad B, Benecke R, Sander D, Markakis E: Evaluation of intracranial pressure from transcranial Doppler studies in cerebral disease. J Neurol 235:159-162, 1988

14. Ling GS, Neal CJ: Maintaining cerebral perfusion pressure is a worthy clinical goal. Neurocritical Care (2):75-81, 2005

15. Marshall LF, Marshall SB, Klauber MR, Van Berkum Clark M, Eisenberg $\mathrm{H}$, Jane JA, Luerssen TG, Marmarou A, Foulkes MA: The diagnosis of head injury requires a classification based on computed axial tomography. J Neurotrauma 9 (suppl 1):S287292, 1992

16. Michel E, Zernikow B, von Twickel J, Hillebrand S, Jorch G: Critical closing pressure in preterm neonates: Towards a comprehensive model of cerebral autoregulation. Neurol Res 17:149-155, 1995

17. Moreno J, Mesalles E, Gener J, Tomasa A, Ley A, Roca J: Evaluating the outcome of severe head injury with trancranial Doppler ultrasonography. Neurosurg Focus 8(1):1-7, 2000, (article 8)

18. Moppett IK: Traumatic brain injury: Assessment, resuscitation and early management. Br J Anaesth 99(1):18-31, 2007

19. Nagai H, Moritake K, Takaya M: Correlation between transcranial Doppler ultrasonography and regional cerebral blood flow in experimental intracranial hypertension (discussion). Stroke 28:603-608, 1997

20. Martin NA, Thomas KM, Caron M: Transcranial doppler techniques, application, and instrumentation. Neurosurg 33 (4):761-764, 1993

21. Robertson CS: Management of cerebral perfusion pressure after traumatic brain injury. Anesthesiology 95: 1513-1517, 2001

22. Saqqur M, Zygun D, Demchuk A: Role of transcranial doppler in neurocritical care. Crit Care Med 35(5):216-S223, 2007

23. Schmidt EA, Czosnyka M, Gooskens I, Piechnik SK, Matta BF, Whitfield PC, Pickard JD: Preliminary experience of the estimation of cerebral perfusion pressure using transcranial Doppler ultrasonography J Neurol Neusurg Psychiatry 70: 198-204, 2001 
24. Sloan MA, Alexandrov AV, Tegeler $\mathrm{CH}$, Spencer MP, Caplan LR, Feldmann E, Wechsler LR, Newell DW, Gomez CR, Babikian VL, Lefkowitz D, Goldman RS, Armon C, Hsu CY, Goodin DS: Assessment: Transcranial doppler ultrasonography report of the Therapeutics and Technology Assessment Subcommittee of the American Academy of Neurology. Neurology 62:14681481,2004

25. Sorteberg A, Sorteberg W:Transcranial Doppler ultrasonography: Part II: Basic principles and applications in neurosurgery. Contemporary Neurosurgery 29(6):1-7, 2007

26. Stacey M, Athanassiou LA, Moppett I, Majahan RP: The effect of systemic arterial compliance on the noninvasive assessment of zero-flow pressure in a bench model of pulsatile flow. $\mathrm{Br} \mathrm{J}$ Anaest 89:96P, 2002

27. Steiner LA, Coles JP, Johnston AJ, Chatfield DA, Smielewski P, Fryer TD, Aigbirhio Fl, Clark JC, Pickard JD, Menon DK, Czosnyka M: Assessment of cerebrovascular autoregulation in head-injured patients: Validation study. Stroke 34: 2404-2409, 2003

28. Steiner LA, Czosnyka M: Estimation of critical closing pressure and cerebral perfusion pressure using transcranial Doppler. Br J Anaest 90: 396-397, 2003
29. The Brain Trauma Foundation. The American Association of Neurological Surgeons.The Joint Section on Neurotrauma and critical Care. Recommendations for intracranial pressure monitoring technology. J Neurotrauma (Supp 1) S45-S54, 2007

30. Tisdall MM, Smith M: Multimodal monitoring in traumatic brain injury: Current status and future directions $\mathrm{Br} J$ Anaesth 99: 61-67, 2007

31. Umamaheswara R, Radhakrisnan M: Benefits and drawbacks of current monitoring modalities in traumatic brain injury. SAARC J Anaest (1):58-66, 2008

32. Weyland A, Buhre W, Grund S, Ludwig H, Kazmaier S, Weyland W, Sonntag $\mathrm{H}$ : Cerebrovascular tone rather than intracranial pressure determines the effective downstream pressure of the cerebral circulation in the absence of intracranial hypertension. J Neurosurg Anesthesiol 12:210-216, 2000

33. White $H$, Venkatesh B: Applications of transcranial Doppler in the ICU: A review. Int Care Med 32: 981-994, 2006

34. White $H$, Venkatesh B: Cerebral perfusion pressure in neurotrauma. A review. Analg Anest 107(3):979-988, 2008

35. Zurynski Y, Dorsch N, Pearson I, Choong R: Transcranial Doppler ultrasound in brain death: Experience in 140 patients. Neurol Res 13:248-252, 1991 